\title{
Exploring Buddhist Teachings and Spirituality in Female Entrepreneurs' Business Decisions in Sri Lanka: The Foundational Role of the Five Precepts
}

\author{
L.E.A.N. Perera \\ University of Kelaniya, Sri Lanka
}

\section{H.A.K.N.S. Surangi}

University of Kelaniya, Sri Lanka

\begin{abstract}
Female entrepreneurship is one of the main drivers of economic and social development in any country. Over the years, a great deal of research has been conducted in the area of female entrepreneurship. However, to date, there has not been much discussion of female entrepreneurs' religious behaviour. Hence, this study examines the nature of female entrepreneurs' religious behaviour and how Buddhist teachings and spirituality influence female entrepreneurs' business decisions throughout start-ups and the ongoing business operations. Although Buddhism is a vast literature, this study focuses mainly on the five precepts. This study is based on social constructionism philosophy, and narrative design was used to explore the female entrepreneurs' religious behaviour. A snowball sampling procedure was applied, and seven interviews were conducted to generate data for the study. This qualitative data analysis was complemented and supported by narrative in-depth interviews, observations and collected documents and field notes. Results revealed that Buddhist female entrepreneurs' business decisions are influenced by their religious teachings, especially the five precepts and religious spirituality. The main themes related to the start-up, operations and pricing, networks, profit sharing, finance, problem solving and sustainability. Further, female entrepreneurs have engaged in solid religious practices in businesses and personal lives since their childhood. Buddhist teachings and spirituality can be identified as the critical factor of Buddhist female entrepreneurs' business
\end{abstract}


success and work-life satisfaction in Sri Lanka. The findings can facilitate and promote spiritual entrepreneurship among entrepreneurs. It is valuable to deepen our understanding of the role of Buddhist teachings and spirituality, which affects entrepreneurs' business decisions.

\section{Keywords:}

Buddhist teachings, Five Precepts, Buddhist spirituality, Female entrepreneurs, Business decisions, Qualitative

\section{Introduction}

The purpose of this study is to explore the nature of female entrepreneurs' religious behaviour and how Buddhist teachings and spirituality influence female entrepreneurs' business decisions from start-ups till the ongoing operations. This research study focuses on the combination of female entrepreneurship and Buddhist spirituality within the Sri Lankan context.

Female entrepreneurship has received much scholarly attention through the last few decades (Hughes et al., 2012; Ahl, 2002). This sector is considered a significant source of economic development and social empowerment in any nation. Female Entrepreneurship is essential for a country like Sri Lanka because females constitute more than half of the country's population. Most probably, females decide to become entrepreneurs as a good option for giving personal and family commitment. It is a practical solution for females who have encountered the 'glass ceiling' in organisations (Ahl, 2002).

There is still less research dedicated to the issue of spirituality and entrepreneurship. The influence of spirituality and religion within the field of entrepreneurship has attracted increased scholarly attention (Candland, 2001). It is generally accepted that religion can shape personal morals and values, influencing individual behaviour and entrepreneurial activities (Audretsch et al., 2007).

Recent entrepreneurship studies have suggested that religious-spiritual influences on entrepreneurial motivation (Parboteeah et al., 2014), new venture creation, entrepreneurial risk-taking, and performance (Ibrahim and Angelidis, 2005). While these studies offer insights into the relationship between religion and entrepreneurship, they focus mainly on Western and Islamic faiths. But this research study focuses on the Buddhist spirituality of female entrepreneurs in Sri Lanka as an Eastern religion and the contribution of Buddhist teachings and spirituality for making decisions related to their businesses. As Buddhism is a vast literature, this research study is based mainly on the "Five Precepts". 
As a cultural component, religion can impact in different ways, people's lives, their behaviour, thinking patterns and attitudes. The impact can be on people's personal lives, career, and businesses. According to the Western perspective, some researchers argue that spirituality is rooted in religion, while others think of these as separate. This study attempts to address the context gap in this setting, and it is placed within the religious behaviour of female entrepreneurs in Sri Lanka.

\section{Literature Review}

\section{Female Entrepreneurship}

The rise of female entrepreneurship has attracted academic interest and developed as a separate research field (Tulus 2009). Scholarly interest in female entrepreneurship is inspired by both the economic and equality-related implications of this phenomenon. The average rate of business start-ups from 1998 to 2014 among female entrepreneurs' $(0.8 \%)$ is low compared to their male counterparts $(2.5 \%)$ in Sri Lanka (UN 2018). Moreover, typical female entrepreneurs' business enterprises are small, with low turnovers, low employees, and no professional assistance. In the process of entrepreneurship, women have to face a more developed range of problems associated with entrepreneurship than men, and these problems can be doubled because of their dual roles as an entrepreneur and homemaker. Not only do women have a lower participation rate in entrepreneurship than men, but they also generally choose to start and manage firms in different industries than men tend to do (Brush 1992).

While Sri Lankan women have made considerable gains in education, this has not yet translated into full access to employment or entrepreneurship. Statistics show that women's participation in entrepreneurial activities in Sri Lanka could be further strengthened, with greater access for women to support services. Women entering the labour market in Sri Lanka are still disadvantaged in finding quality paid employment; they must often look for other sources of income, notably self-employment. Women operate their businesses, which tend to be in the most disadvantaged sectors, predominantly in agriculture, tourism, handicrafts, and garments. Even those who specialised in industry and services tend to concentrate on a limited number of activities, such as catering, tailoring, beauty and food processing. Women-owned businesses often lag behind maleowned enterprises in terms of size, productivity and tend to be less profitable, with little potential for further expansion and have a high failure rate. 
In most Asian countries such as Sri Lanka, women are viewed as weak, passive, obedient or submissive. Furthermore, dominant religious beliefs and traditions do not favour women being involved in outside activities (Ram and Seela 2010). In some cases, society has stereotyped them as being a weakness in a man's life, should his wife be working or involved in the business. When women are engaged in business activities, they have to deal with many people and sometimes travel away from their homes and participate in business gatherings. Such activities are not well accepted by Asian societies (UNESCAP 2005, Ram and Seela 2010, Surangi 2018). The Sri Lankan society is still patriarchal; Sri Lankan women are traditionally considered homemakers and not business people. Women's family obligations also bar them from becoming successful entrepreneurs in both developed and developing nations (García and Welter 2011). Having primary responsibility for children, homes and elders, few women can devote their time and energy to their business (García and Welter 2011). In this setting, inherited customs and social norms create pressure by reinforcing gender stereotypes, constituting one of the main constraints for female employment and entrepreneurship in Sri Lanka. As women need to balance business or jobs with the demands of family and household care, they have to pursue economic activities that offer fewer career opportunities, that are less innovative and typically confined to traditional roles.

As entrepreneurship is considered a significant source of economic growth, employment, poverty alleviation, regional development and innovation, women are a readily available resource that different stages of economic development may use to accomplish economic progress (UN 2018). Historically, most Asian societies have been patriarchal, with the woman considered as a secondary person. Gender equality is vital to economic and human development in a country. Removing gender inequalities provides society with a better chance to develop. Therefore, encouraging women to become involved in entrepreneurial activities may lead to economic prosperity and improve their living standards.

\section{Entrepreneurship and Religion}

The entrepreneurial process is influenced by the religious/spiritual values of the entrepreneur (Balog et al., 2014). These influences can be categorised as macrolevel and micro-level. Entrepreneurial decision making occurs at every stage of the entrepreneurial process (Shepherd et al., 2015) and comprises intention, opportunity discovery, feasibility, launch, and functioning of the business. Therefore, the entrepreneurial decisions made at these stages are also influenced by the spiritual/religious values of the entrepreneur. 
In literature, most scholars have addressed Christian and Islamic religions and spiritualties concerning management and entrepreneurship. According to the scholars' findings, Christians run their businesses based on Christian values and principles, and entrepreneurship provides an opportunity to use their talents to the glory of God (Cullen et al., 2013). Christian spiritual tradition profoundly informs and shapes the leadership of Christian spiritual leaders (Delbecq, 1999). In findings, Islamic spirituality is highlighted as the critical role of the success of Muslim female entrepreneurs (Grine et al., 2015). In general, the majority reflects a strong relationship between religion and spirituality of the entrepreneur and his/her business decision making. In contrast, some scholars have argued that religion does not foster entrepreneurship in any mean (Cousins, 1996).

\section{Buddhist Teaching and Spirituality}

Buddhist Teachings are the preachings of Lord Buddha. Lord Buddha was a teacher, philosopher and spiritual leader who is considered the founder of Buddhism. The Three Universal Truths, Four Noble Truths, and Noble Eightfold Path are the Buddha's basic teachings, the core of Buddhism. The Dharma begins with the "four noble truths" (Dunn \& Jensen, 2019). According to the Buddha's teachings, ethics are the foundation for all good qualities we can develop in our minds. We can eliminate worry and regret and all the unpleasant results of unwholesome actions by following five basic training rules called the "five precepts". These precepts are selected as the Buddhist teachings for this research study, as Buddhism is a vast literature.

Buddhist spirituality is concerned with the end of suffering through an enlightened understanding of reality. All spiritual practices of the Buddhist tradition are oriented towards ultimate freedom from suffering and the cultivation of wisdom and compassion. Buddhist spirituality is not about absenting oneself from this reality, but rather fully, completely, and courageously facing it. It is imminently practical and provides discipline for the mind and the body, for treating others and oneself. It shows us how to love others, instead of saying "Love others", and it shows us how we may become wise instead of merely saying "Be wise". Buddhist spirituality may be compatible with other religious perspectives because it is practical rather than theoretical (Dunn \& Jensen, 2019).

\section{Entrepreneurship, Religion and Spirituality}


Theory of planned behaviour (TPB) that "predicts and explains behaviour in specific contexts" is a frequently used theory in different disciplines. This theory is valid for entrepreneurship research because becoming an entrepreneur is considered a conscious activity, and the intention is considered a cognitive state. Further, it is argued that entrepreneurial decision is a complex one and needs an intentional mental process. Also, there is an argument that strategic entrepreneurship is considered an intentionally planned behaviour, which is valid for even necessity motivated and unexpected entrepreneurship. Therefore, studying the decision-making process for entrepreneurial behaviour via the theory of planned behaviour (TPB) seems reasonable (Sabah, 2016).

Institutional theory attends to the deeper and more resilient aspects of social structure. A growing subfield of institutional theory considers institutional logics, broadly (but not universally) shared assumptions and action patterns (Thornton \& Ocasio, 2008). At the organisation level, institutional logic can be seen as sources of managerial decision-making rules. Institutional theory has also shifted into examining the founding conditions for new firms (Tolbert et al., 2011).

According to the literature, religion and spirituality influence decision making. Buddhism influences ethical decision-making in organisations as a religion and a great philosophy (Jayawardena, 2017). Buddhist concepts of Right Livelihood play an essential role in evaluating and exploiting entrepreneurial opportunities and the day-to-day operations of the resultant new businesses (Valliere, 2008). The role of religion in influencing the likelihood of choosing self-employment suggests an essential link between religion and occupational decision-making (Audretsch et al., 2007). Religion plays a significant role in affecting the judgment, emotional and motivational qualities of Sri Lankan business leaders' decision making (Fernando \& Jackson, 2006). There is a possibility of applying the practical wisdom of Buddhism into the individual, group and organisational decision-making processes, and business organisations and business schools can use the practical knowledge gleaned from the Buddhist traditions. Islamic spirituality on Muslim female entrepreneurship in Malaysia shows the effects of spirituality on shaping their decision-making (Grine et al., 2015). Organisational and management practices are influenced by both religion and spirituality. Buddhism is a prevalent religion throughout many parts of the world, and Buddhist culture and beliefs are manifested through Buddhist business practices (Dunn and Jensen, 2019). Buddhist concepts and procedures are adequate to be applied in organisational management, and hence these concepts and techniques have a universal application that could improve organisational productivity 
(Weerasinghe et al., 2015). Buddhist teachings are essential for understanding management as practiced in Buddhist countries and that such practices have universal application and appeal (Rarick, 2007). Buddhist concepts impact leadership, team building, personal development, conflict and people management (Ashtankar, 2015). Applying Buddhist practical wisdom contributes to achieving more beneficial economic outcomes and management practices (Kovács, 2014).

Some scholars researching this area have found some relationships between religion, spirituality, entrepreneurial behaviour, or activity. Religion is one of the vital cultural influences and socialising factors shaping females' gender role attitudes and values, affecting the characteristics of their entrepreneurial behaviour (Rogers \& Park, 2014). Intrinsic religious motivation positively influenced potential entrepreneurial activities (De Noble et al., 2007).

Buddhist values and associations can bring unique benefits to new ventures founded by Buddhist entrepreneurs and help improve recent venture performance (Liu et al., 2017). Sustainable businesses are achieved through the influences of Buddhist teachings (Sachayansrisakul, 2016). Religiosity may contribute to entrepreneurial success. Hence, in the presence of personal religiosity, the entrepreneurs' pursuit of material wealth does not lead to dysfunctional outcomes but rather to greater degrees of life satisfaction (Bellu \& Fiume, 2004). Christian-based companies experience higher sales, more significant increases in personnel, and higher productivity (ROI) (Ibrahim \& Angelidis, 2005). Entrepreneurs' personal religious and spiritual beliefs influence managerial practices, but values are not related to entrepreneurial motives (Morris \& Schindehutte, 2005).

Muslim females in Malaysia have made significant inroads into entrepreneurial decision-making by capitalising on religiosity and spirituality, providing them with guidance, support, satisfaction, and balance (Grine et al., 2015). Islamic Spirituality is a key motivator for the ambition of Muslim females to succeed in their business and increase their work performance (Grine et al., 2015). Belief in the Islamic religion is related to motivation and commitment towards socially responsible business activities (Graafland et al., 2006).

As a robust cultural dimension, religion influences females' entrepreneurial processes and aspirations (Mazonde and Carmichael, 2016). Religious beliefs have a positive effect on their entrepreneurial activity in three aspects; by influencing the decision to become an entrepreneur (motivation), how they manage their enterprises (decision-making and managerial practices) and in 
their internal and external networks (Dodd \& Seaman, 1998). Some scholars have presented contradicting findings that religion has no impact on entrepreneurial pursuits or entrepreneurial success (Nair \& Pandey, 2006). According to scholars' findings, Christian entrepreneurs and Muslim entrepreneurs run their businesses based on their religious principles and values (Kayed \& Hassan, 2010). There is a relationship between Buddhist entrepreneurs' spirituality and their right decision-making (Jayawardena, 2017). Buddhist doctrine within the socio-cultural context played a significant role in evaluating and exploiting entrepreneurial opportunities (Valliere, 2008).

Research investigating female entrepreneurs has developed considerably over the past two decades. However, female entrepreneurs' religious values and spirituality are still relatively under-researched and represent a challenging research field. As identified in this study, female entrepreneurs' decision and their religious values and spirituality is yet to be developed in methodological, theoretical and conceptual terms. Researchers from different academic disciplines, particularly those of Business, Economics and Sociology, have discussed the concept of religious values and spirituality. However, a general conceptual framework for investigating this area is still absent. Thus, we can see that the focus of empirical studies on female entrepreneurs' religious values and spirituality has been limited. So far, minimal empirical studies have been conducted in developing countries in this regard. Therefore, there remains an opening for theoretical and empirical research in female entrepreneurs' religious values and spirituality, focusing on the Foundational Role of the five precepts.

\section{Methodology}

This qualitative study aims to capture and understand the complex social phenomenon of female entrepreneurs' religious behaviour and is thus grounded in the interpretive paradigm. The narrative methodology focuses on the life experiences of a single event or a series of events or the detailed stories of a small number of individuals (Creswell, 2007). It is crucial to know Buddhist female entrepreneurs' life stories/experiences or past incidents to achieve the particular research objectives of the study. Knowing their life story is essential to understanding their attitudes and how their life experiences affect shaping them. It helped the researcher realise how religious teachings and spirituality influence the business decision-making among Buddhist female entrepreneurs in Sri Lanka. 
The interviews, observations and documentary analyses taken in this study are consistent with the research objectives and methods used in similar studies. Seven female entrepreneurs were purposively selected and interviewed. Heterogeneity was a central guiding principle for selecting the sample. The researcher identified saturation point as the narratives began to reveal similar things. Before each interview, researchers obtained oral consent to record the interviews digitally.

Additionally, field notes were prepared based on the observations.

Thematic analysis was used to analyse the collected materials. First, interview transcripts were reread and reviewed several times, searching for "repeated consistencies". Researchers highlighted quotes and phrases from the interviews. Using the constant comparative method, the researcher went back and forth among transcripts until categories emerged that were consistent yet distinct. The researcher named these categories, coded and indexed the transcripts, and placed sections in labelled folders representing each category. Second, the researcher brought together the coded interviews, and looked for relationships within and across the data sources. A table was developed to compare various coded interviews. Finally, the researcher integrated and refined the categories until themes solidified. Moreover, the ethical procedure was applied at every stage of the research process, including informed consent and confidentiality.

\section{Findings and Discussion}

\section{Themes derived from narratives of Buddhist female entrepreneurs}

The current study focuses on two research questions. The researcher derived the themes separately to support the research questions. In the first research question, the researcher attempted to identify "What is the nature of female entrepreneurs' religious behaviour?" The nature of female entrepreneurs' religious behaviour (emergent themes) is presented in Figure 1. 


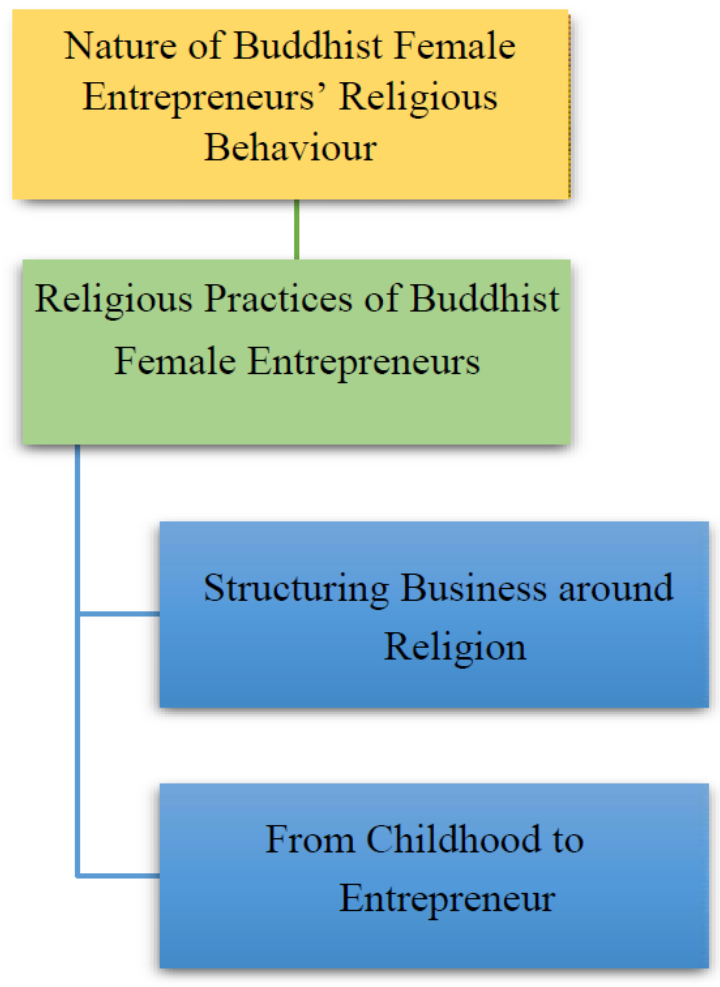

Figure 1: Nature of female entrepreneurs' religious behaviour

Source: Developed by the researcher based on the outcome of this research

\section{Nature of Buddhist female entrepreneurs' religious behaviour}

According to the literature, female entrepreneurs follow various religious behaviours in their businesses and personal lives depending on their religion and belief. Muslim female entrepreneurs practice religious rituals such as praying, fasting, charity and pilgrimage to Makkah (haj) and zakat (a form of almsgiving considered in Islam as a religious obligation or tax, which, by Quranic ranking, is next after prayer) is observed regularly (Grine et al., 2015).

First, the researcher reveals the religious practices of Sri Lankan Buddhist female entrepreneurs in their business.

\section{Structuring business around religion}

According to the responses of the interviewed Buddhist female entrepreneurs, they exhibit strong religious practices in their business. They have given priority 
to religious and traditional rites in their businesses. Starting a business after worshipping Lord Buddha and involving pirith (the Buddhist practice of reciting certain verses and scriptures to ward off misfortune or danger) in their business environment proves how they prioritise religious beliefs and how their religious spirituality works. Furthermore, they also offer incense and the prime portion of food they cook to Lord Buddha as a practice in their businesses. On special days of every year, on the days like the 01st of January, Sinhala and Tamil New Year day and the first day they start their business, they offer alms to monks or the clergy. By the time they start their businesses proper, they have completed all the initial religious tasks in the opening ceremony of the business. All of the information very clearly shows that their business is structured upon Buddhist teachings and spirituality. During these instances, the 'five precepts' of their Buddhist spirituality act as the house's foundation. All of their businesses are structured on Buddhist culture and are seen as a religious orientation. The quotations indicated below specifically prove the details described above regarding Buddhist female entrepreneurs' religious practices in business.

"We offer a prime portion to Lord Buddha when we prepare food in our business" (Participant \# 1)

"Even now we offer incenses and chant pirith every morning and evening in our business place" (Participant \# 6)

"We do almsgiving to clergy on 01st of January, Sinhala and Tamil New Year day, and the day we start the business" (Participant \# 4)

These responses powerfully demonstrate that Sri Lankan Buddhist female entrepreneurs perform and follow religious practices in their businesses, and they have established a better religious background in their business environment. Findings have complied with Sachayansrisakul (2016) as Buddhist female entrepreneurs in Thailand are regular temple visitors, perform the basic religious rituals like merit-making and food offerings to the monks, pray regularly, meditate, and follow all the teachings by heart (Sachayansrisakul, 2016).

\section{From childhood to entrepreneur}

Apart from this, Buddhist female entrepreneurs in Sri Lanka follow strong religious practices in their personal lives since their childhood. They have an excellent religious family background. Mainly their parents have influenced 
them to be good Buddhist practitioners since their childhood. They accepted that these religious practices had provided them strong support to be more ethical and well-disciplined entrepreneurs. The following responses of Buddhist female entrepreneurs display their religious practices from childhood to their entrepreneurship.

"I have worked as a teacher of a Dhamma school" (Participant \# 1)

"I perform Bodhi Pooja, and I also perform a Pooja for nine planets and gods" (Participant \# 2)

"I listen to Dhamma" (Participant \# 2)

"I worship Lord Buddha every morning and chant pirith every evening" (Participant \# 4)

"I meditate for some time once a day" (Participant \# 4)

After becoming entrepreneurs, they perform Bodhi Pooja, and whenever they have any free time, they visit the temples. Some of them have made it a habit to meditate once a day. They worship Lord Buddha every morning, and they chant pirith as well. Similar results have been found in the USA (Griebel, Park and Neuburt 2014). Studies reveal that religion impacts many different areas of a person's life, such as family politics and gender roles and vice versa (family affects religious behaviour).

\section{How do Buddhist teachings and spirituality influence female entrepreneurs to make their business decisions?}

In the second research question, the researcher attempted to identify, "How do Buddhist teachings and their built-up spirituality influence business decisions, from the start-up till the ongoing business operations?" Figure 2 shows eight significant themes and three sub-themes derived from the female entrepreneurs' stories related to the second research question. 


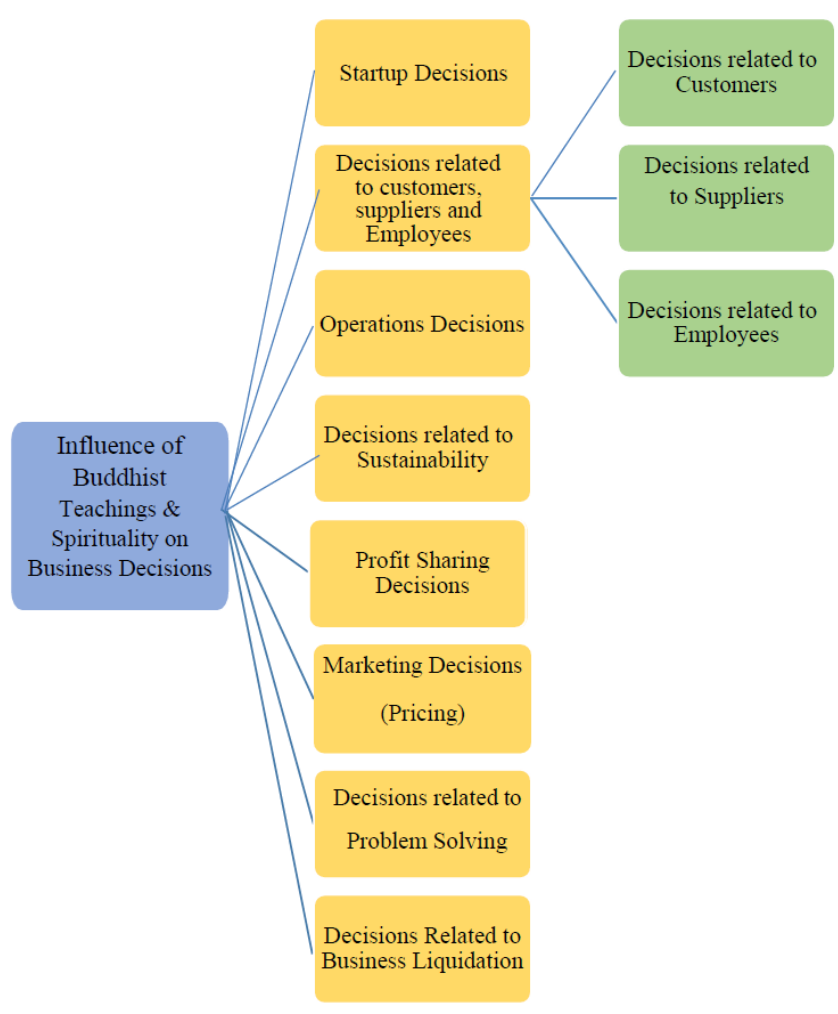

Figure 2: How Buddhist teachings and spirituality influence during the start-up through to the ongoing business operation.

Source: Developed by the researcher based on the outcome of this research

\section{Start-up decisions}

According to the participants' responses, they had considered the five precepts when they started their businesses. Their built-up Buddhist spirituality influenced them to start a legally accepted and ethical business. Lord Buddha advises the laity to avoid five specific trades, which creates negative karmic results if engaged in. "Five trades that a disciple should avoid are: Trading in arms, in living beings, in the flesh, in intoxicating drinks, and poison" (Griebel, Park and Neuburt 2014). The above trades are to be avoided if we wish to sustain the spirit of Buddhism by implication of that advice. Practicing the above advice assists in upholding the first precept and the fifth precept. Sri Lankan Buddhist female entrepreneurs also consider this advice when they make their start-up decision. 
"My restaurant is a pure vegetarian restaurant, which means there is no animal slaughter in our business, and our business is based on the first precept. It is also the cause to start this kind of business" (Participant \# 4).

"I focused on this type of business by thinking of virtue and sin" (Participant \# 7).

Mainly, these respondents are most concerned about conducting their businesses without harming any living beings. They want to help others and be the happiest person by carrying out their businesses in a righteous way. Therefore, they believe in Karma and have adopted their whole business processes accordingly. Some female entrepreneurs have decided to start a business to be good mothers. The Sigalovada Sutta sets out the five traditional duties of parents toward their children. The above responses display how the five precepts and Buddhist spirituality influence female entrepreneurs to make their start-up decisions. These findings are contradicted with Weber's famous theory as he suggested that those who participate in the economic realm would eventually no longer need religion (Weber,1930). However, many studies demonstrate that people do not see work and religion as entirely distinct spheres.

\section{Decisions related to networks of employees, customers, and suppliers}

\section{Decisions related to customers}

After analysing the decisions taken by female entrepreneurs on their networks, especially on employees, customers and suppliers, the researcher identified that Buddhist female entrepreneurs have adopted the five precepts and that the Buddhist spirituality influenced their attitude-based entrepreneurial behaviours.

"I never lie to my customers, and I provide accurate information to my customers regarding nutritional status of fruits" (Participant \# 1)

"When the sangha come to my juice bar, I never take money from them" (Participant \# 1)

"I treat every child in my pre-school equally" (Participant \# 3)

"Even if we make a small mistake, it bothers us. Some flower plants do not grow properly. Some customers like to buy these flower plants as well. There have been instances where I have told them the truth and sold them" (Participant \# 6) 
The responses above reflect that especially Buddhist female entrepreneurs have adopted the fourth precept by not lying to and cheating their customers. Their Buddhist spirituality has led them to make more ethical decisions when conducting their businesses. Here, one of the respondents says that she never charges money from the Buddhist monks who are customers. Buddhist spirituality hugely influences the making of such decisions. They treat their customers equally, and the customers too have faith and pleasant, genuine feelings on Buddhist female entrepreneurs' behaviour. These female entrepreneurs do their best to delight customers and offer more quality products. According to their responses, they cannot commit even a tiny mistake to their customers, as it would make them feel guilty and create bad feelings. Rarick (2007) explained how entrepreneurs combine their values and business decision towards customers. Thus, these entrepreneurs have found a way to make their work-lives compatible with their values and create a new work ethic in treating customers.

\section{Decisions related to suppliers}

Suppliers are also critical stakeholders, and they are considered one of the essential parts of any business. Therefore, maintaining good relationships with their suppliers affords many advantages to entrepreneurs and business owners (Surangi, 2018). The following responses show how Buddhist female entrepreneurs make decisions regarding their suppliers and how the five precepts and Buddhist spirituality guide them at such times.

"I never bargain with my suppliers and work with my suppliers fairly" (Participant \# 1).

"We have a supplier for our business. I'm not cheating him, and pay money at the right time. Therefore, he has been supplying leaves for my business for six years" (Participant \# 7).

According to the above responses, Buddhist female entrepreneurs have followed the fourth precept by abstaining from lying. They have paid their suppliers without any delays. Also, they never bargain unnecessarily with their suppliers. Buddhist female entrepreneurs believe that they should also satisfy the suppliers just like the customers, or they cannot run their businesses continuously. Therefore, they avoid unfair bargaining for prices. They especially maintain a very genuine relationship with their suppliers. Women in the study select raw 
materials that they want. If not, any inferior quality raw materials or products may cause issues from the customers' perspectives. They balance everything in their businesses without missing anything and pay equal consideration to all aspects, and this is all about the ethical behaviour of entrepreneurs. A widespread claim in the literature is that religious belief is likely to enhance ethical decision-making across business groups (Sabah, 2016; Rarick, 2007). If this were so, one could argue that the behaviour of entrepreneurs would be contingent upon the ethical constraints imposed by their religious beliefs (Sabah, 2016; Rarick, 2007).

\section{Decisions related to employees}

Employees are the key drivers of any business. Human capital is the most important and valuable factor of any business and hence maintaining good relations with them and managing human resources well provides competitive advantages. In this regard, the employee-related decision making is fine-tuned by the five precepts and Buddhist spirituality. The responses reveal how this happens.

"When I select an employee for the post of a cashier, I see whether that person is honest or not. All employees should be capable enough to treat our customers pleasantly (Participant \#1)

"At least I never steal the labour of my employees. I provide a reasonable salary for them with free food and accommodation. Consumption of alcohol is strongly prohibited within the business premises and also within the boarding place for employees" (Participant \# 4)

When hiring employees, they look at the employees' personal qualities, such as honesty, integrity, patience, and how pleasantly they treat their customers. These entrepreneurs have adopted the second and fourth precepts because they do not hire thieves, loiterers, liars and cheaters as their employees. The above responses prove that they never commit any financial fraud on their employees. Buddhist female entrepreneurs pay salaries on time to their employees, and they also provide other facilities like food and accommodation free of charge. They highly appreciate employees' discipline and strictly prohibit alcohol consumption during working hours within the business premises and boarding places. These aspects are also taken into consideration when hiring employees. Therefore, the researcher realised how they practice the fifth precept. 
Furthermore, these female entrepreneurs also want to create quality and better working environments for their employees to work without hassles. They have given the freedom to their employees to carry out their work. The researcher of this study also stresses that when making the above kind of decisions, the five precepts and Buddhist spirituality have remarkably influenced the decisionmaking process of the Buddhist female entrepreneurs in Sri Lanka.

\section{Operational decisions:}

According to the female entrepreneurs' responses, operation decisions are also influenced by the five precepts and Buddhist spirituality.

"I use only natural products in my salon. Even when I'm doing a facial, I start it after invoking blessings" (Participant \# 2)

"When we are cooking a meal, we never use things like artificial flavours. We give everything with good intentions" (Participant \# 4)

"We use the exact amount in the mix because if the blend goes wrong, the pottery will explode. So, we do the mixing properly without faking" (Participant \# 5)

The above responses showed us how female entrepreneurs follow the five precepts, especially the first, second and fourth precepts. Buddhist spirituality also assisted them in making such operation decisions. They never sell poison nor use artificial flavours and harmful chemicals in the operation processes to maximise profits. This means that they follow the first precept by abstaining from killing living beings. Instead, they want to create healthier customers in the society. It proves their adoption of Buddhist teachings and spirituality. They never compromise in the operation process; especially when mixing raw materials, they use the correct and sufficient amounts when implementing operational tasks. Therefore, they follow the second and fourth precepts without stealing and lying to their customers. They do everything with pure and good intentions, and they believe that doing business the right way adds merits to their lives. These findings are similar to current knowledge in the area. Some studies report that religious respondents exhibit higher degrees of ethical sensitivity towards operational decisions and are less likely to behave in an unethical fashion (Angelidis and Ibrahim, 2004). 


\section{Decisions related to sustainability}

Most business owners miss sustainability when carrying out their businesses. But Buddhist female entrepreneurs pay attention to the people, planet and profit while carrying out their businesses. Their responses show how sensitive they are to the environment and the people and maximise profits. They think of the future, and accordingly, they have altered their decisions without causing any harm to the environment. In this regard, Buddhist teachings and spirituality have had a considerable influence.

"We must give a portion of what we receive now in this spirit even if we have been in the world of business for a long time. I've been carrying out a salon for 20 years" (Participant \# 2)

"We are eco-friendly. In our business, we never use polythene and plastics" (Participant \# 4)

"The business has a good existence when it comes to religion" (Participant \# 6)

"Because we have not cheated people, we can continue our business for a long time." (Participant \# 7)

According to the Buddhist female entrepreneurs, they have continued their businesses for a long time as they have not harmed society and the environment. They have carried out all their business processes without polluting the environment. They have always tried to minimise the negative impacts on society and the environment caused by business operations. Sustainable businesses and green businesses strive to address the triple bottom lines called people, planet and profit. Generally, sustainability in business addresses two main categories (Spiliakos, 2018).

- The effect the business has on the environment

- The impact the business has on society

According to Lord Buddha's advice, Buddhist female entrepreneurs have incorporated their business decisions of not causing any harmful effect on the categories mentioned above and ensure sustainability in business. Therefore, they have followed the green practices in their business, like reducing or prohibiting polythene and plastic consumption and maintaining an eco-friendly 
business. These findings are similar to Worden's framework. He proposed a normative analysis of the ethical dilemmas inherent in applying religious content to secular environments and then considered the strategic implications of this application for organisational performance and sustainable competitive advantage (Worden, 2005).

\section{Profit-sharing decisions}

Profit-sharing is another type of decision in business. Buddhist female entrepreneurs allocate their profits for religious tasks and the betterment of society as Buddhist teachings and spirituality shape them. They do not forget to invoke merits when they earn profits from the businesses. The following responses show us very clearly how they allocate or share their profits for social welfare.

"I provide fruits or juices when my villagers or neighbours need them for almsgivings, and most of the time I provide all of them only at cost" (Participant \# 1)

"We visit children's homes on Children's Day and offer alms to disabled children" (Participant \# 3)

"We can't go to the temple very often; if a beggar comes here, I never send him away without giving anything. If a monk comes here, the same thing happens. We conducted a dan sala for five years with the profits earned from the business" (Participant \# 7)

The profits from the businesses are used for religious tasks, charity purposes and the betterment of people faced with more significant social and economic difficulties. To make this kind of business decisions, especially their attitudes, are influenced by Buddhist teachings and spirituality. However, related to profit sharing decision, these findings contradict the literature as some researchers have termed "love of money" to prevail religious precepts as a motivating factor, even for believers (Sabah, 2016; Rarick, 2007).

\section{Marketing decisions}

Marketing is an essential function in any business. Marketing mix mainly comprises of 4P's called price, place, product, and promotion. Here Buddhist 
female entrepreneurs primarily emphasise how they decide on their pricing by incorporating Buddhist teachings and spirituality.

"I look at the current situation and compare it with the other salons and try to offer a better quality of service for a lower price than my competitors" (Participant \# 2)

"I set affordable prices to my customers anyway, and I do not make decisions based on money. Always I want to offer something more than the money. It was something I gained from Buddhism" (Participant \# 2)

"We fix the price of food through costing but not unfair to consumers. Many people say that our prices are very reasonable" (Participant \# 4)

They earn money from the businesses by establishing fair prices for their products. They never allocate higher prices because they consider the customers' perspectives without paying attention to profit-maximising and self-interests. Especially they set reasonable prices which customers can afford. They never set prices beyond the reach of their customers. Similar evidence was found in a study done by Rogers \& Park (2014) as they found that a reduced acceptance of problematic ethical behaviour was connected with a higher degree of religious salience for respondents, that is, for those respondents who agreed that religion was significant in the making of marketing decisions.

\section{Finance-related decisions:}

Finance is another critical business function, and without making better financial decisions, it isn't easy to progress in the business world. Every entrepreneur or business person must carefully handle it, or else they may have to face bankruptcy and may even end up with liquidation. In this regard, Buddhist teachings (the five precepts) and spirituality are incorporated by Buddhist female entrepreneurs to make more precise financial decisions.

"I'm not in debt, and I don't obtain too much debt" (Participant \# 2)

"The Mahara Divisional Secretariat provides us with loan schemes, and I pay them systematically. They check to see if my business is doing well before lending" (Participant \# 6) 
"I took loans from the Regional Development Bank to develop my business. I'm paying loan instalments systematically. That is where trust comes in" (Participant \# 7)

According to the above responses, it is evident that they pay their loan instalment to the respective lenders without defaulting, especially to banks and other government institutions. They have been granted the privilege to obtain such loans since they fulfil the relevant criteria. Therefore, by making such decisions to pay loan instalments on time, they have gained the trust of the respective loan providing parties. Here they have adopted the second and fourth precepts from among the five precepts. They have qualified to manage their loans without any defaults.

Furthermore, their customers are very loyal to them, so they set off loans they have obtained. They have obtained loans for their business development based on the requests of their loyal customers. Hence, they are more sensitive to customer requests as well. The five precepts and Buddhist spirituality have also served them remarkably to make better financial decisions without losing or heading towards bankruptcy. Moore and Buttner (1997) also concluded that the beliefs of the participants shaped their entrepreneurial activities since their "search for profits had to be in harmony with the natural order rather than being motivated by self-interest alone."

\section{Decisions related to problem-solving}

When running a business, all entrepreneurs face some troublesome situations. Buddhist teachings and spirituality render great assistance to Buddhist female entrepreneurs to manage and resolve such cases far more quickly. The following responses indicate such grants have enabled them to successfully handle the problems they had faced in their business operations.

"I learned the eight worldly concerns from Buddhism. According to that, I know how to deal with any problem. By thinking that way, we can decrease our stress and realise the reality of the particular problem" (Participant \# 4)

"It is something great that I have received from Buddhism to endure any problems in my business" (Participant \# 4)

"On rainy days, we cannot meet our sales targets, but our sales are much better on sunny days. So, at the same time, we tolerate these two consequences by 
thinking about the world's reality. Buddhism reminds us that gain and loss are the opposite sides of the same coin" (Participant \# 4)

In such instances, the eight worldly concerns provide them with more patience to face unfavourable business conditions. However, during such cases, they have also experienced a drop during certain seasons. But Buddhist female entrepreneurs face such situations with a positive mind. The eight worldly concerns in Buddhism are gain vs loss, fame vs insignificance, praise vs blame, happiness vs suffering. According to those things, they often balance and resolve their business problems successfully by reflecting on these philosophies. Their responses reveal how important Buddhism and spirituality are to make the best decisions to overcome their business problems better. According to them, their personal qualities matter a lot when dealing with difficulties and these qualities are shaped by adopting Buddhist teachings since their childhood. They know how to manage such bad experiences without any conflicts by reducing their stress and anxiety.

\section{Decisions related to business liquidation}

Liquidation in finance and economics is the process of bringing a business to an end and distributing its assets to the claimants. The researcher wants to stress what happens when a business run by Buddhist female entrepreneurs must be closed down permanently. Hence, the decisions they make regarding at what stage of the business cycle the business should be liquidated and the adoption of the five precepts and the following spirituality to make these business decisions are highlighted by the researcher of this study through the following quoted texts:

"I do not embrace this business" (Participant \# 2)

"I will hand over my business to the children if they wish to continue this business, and I'm pleased about that because my children love this business" (Participant \# 4)

Lord Buddha's teachings are based on how to free one's self from sufferings. Therefore, a strong bond with anything material is pointless because everything perishes and changes with time and nothing is permanent in this world. Buddhist female entrepreneurs have also realised this truth. They never want to run their businesses till the end of their lives but want to hand over the businesses to the succeeding generations. They are usually prepared to give up 
their businesses at the correct time without any hesitation. They have already decided to hand over their businesses to their children if they wish to continue. On the other hand, they also never force their children to take over the businesses after them. According to them, embracing anything too strongly is pointless, and they should refrain or free themselves from such intentions. They have been taught such concepts or ideas due to their familiarity with Buddhism. As a whole, we can identify the kind of religious behaviours Buddhist female entrepreneurs follow and how Buddhist teachings and spirituality influence them to make such business decisions. Accordingly, individuals practicing spiritual leadership at a personal level will experience greater psychological well-being, life satisfaction and physical health: they will also develop a sense of meaningful and purposeful life and an ability to follow their inner convictions that culminate in a state of self-realisation, in alignment with the cultivation of good-quality interpersonal relations (Fry 2003).

\section{Conclusion}

This research explores how female entrepreneurs' business decision-making is shaped by Buddhist teachings (the five precepts) and spirituality. The influence of religion on work has not been fully explored in the Sri Lankan context, particularly the relationship between religion and entrepreneurship as a specific type of work. Therefore, this study examines the link between female entrepreneurial behaviour towards their decision-making and religion. The study finds that religion, for female entrepreneurs, is highly individualised, and religion shapes entrepreneurial activities.

These research findings contribute towards enriching female entrepreneurship literature. These findings provide a new aspect to define female entrepreneurs by highlighting their religion and spirituality. Spiritual entrepreneurship literature is also enhanced through these research findings as the current study is focused on Buddhism as a religion. In the spiritual entrepreneurship literature, Buddhist spirituality opens a new window to more explorations as well.

Moreover, the model was developed by the researcher based on the research findings of the current study. This model exhibits the nature of the religious behaviour of Buddhist female entrepreneurs and how the Buddhist teachings (the five precepts) and spirituality influence their business decision-making. This business model comprises ten themes and five sub-themes. The nature of religious behaviour can be classified under two conditions: religious practices in 
Buddhist female entrepreneurs' personal lives and business lives. The influence of the five precepts and Buddhist spirituality on various business decisions is quite evident. They are decisions related to start-up, networks (employees, customers and suppliers), operations, sustainability, finance, marketing (pricing), problem-solving, profit-sharing and liquidation. The objective is not to establish a positivist proof of the framework; instead, the model aims to demonstrate its acceptability and how it helps readers to understand why religion and spirituality are influencing female entrepreneurs' decisions. This explanation, along with the analyses in Figure 4 and the literature review, provide a basis for the development of the model (Figure 4)

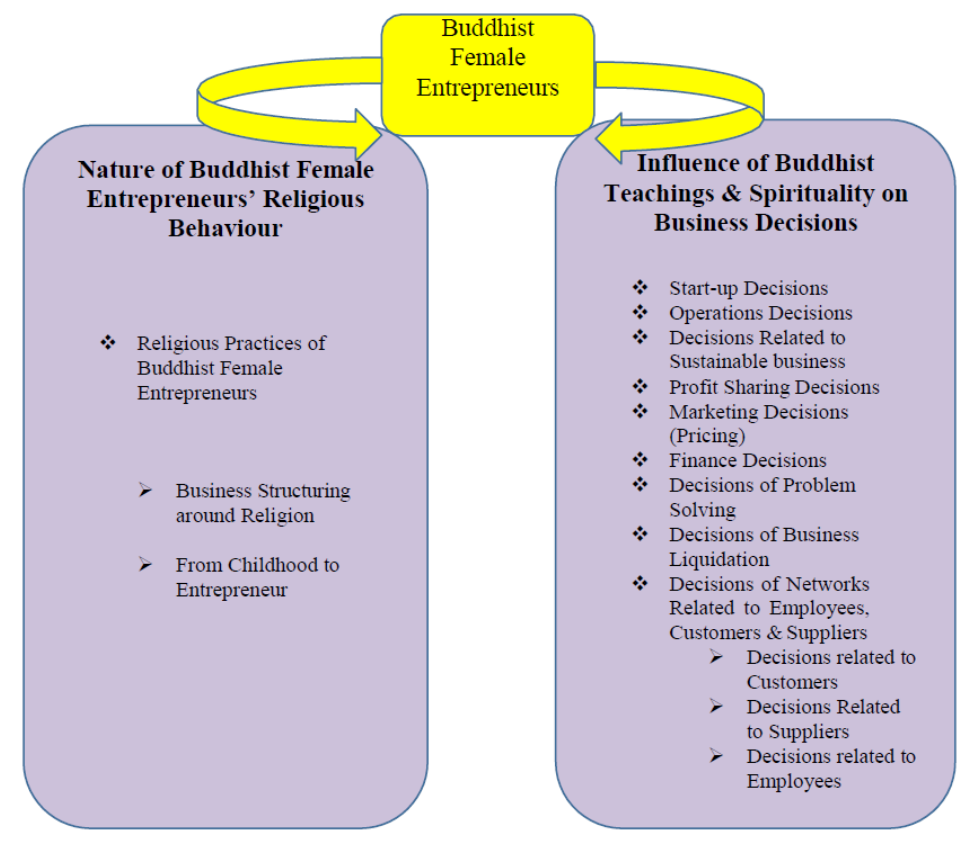

Figure 3: Proposed Model for Buddhist Teachings and Spirituality in Female Entrepreneurs' Business Decisions

Source: Developed by the researcher based on research findings

It is proposed that there are at least two practical applications for the model. One is educational; the other is for business practitioners. Educationally, there is a need for a model of Buddhist teaching, spirituality and entrepreneurship, which researchers can use as a basis. Further, the model will be used by policymakers of countries to develop an ethical framework for entrepreneurs and business persons as a better drive to society towards sustainability and 
transparency while improving the businesses. This ethical framework will help reduce fraud and corruption in the business world and ultimately create a better community. These findings lead all business persons to conduct more sustainable businesses by considering the profit, people, and the planet. This research study provides an excellent motivation to engage in more ethical businesses by making the right decisions. This article can be considered as a guide to all entrepreneurs and business persons not only to be a mere entrepreneur but to be a spiritual entrepreneur as well.

\section{Declaration of Conflicting Interests}

The authors declared no potential conflicts of interest with respect to the research, authorship, and publication of this article.

\section{References}

Ahl, H. J. (2002). The Making of the Female Entrepreneur A Discourse Analysis of Research Texts on Women's Entrepreneurship. Int. Handelshögsk.

Angelidis, J. and Ibrahim, N. (2004). An Exploratory Study of the Impact of Degree of Religiousness Upon an Individual's Corporate Social Responsiveness Orientation. Journal of Business Ethics, 51(2), 119-128.

Ashtankar, O.L. (2015). Relevance of Buddhism for business management. International Journal of Applied Research , 1(13): 17-20.

Audretsch, D.B., Bönte, W., Tamvada, J.P. (2007). Religion and Entrepreneurship. SSRN Electron. J. https://doi.org/10.2139/ssrn.1025968

Balog, A.M., Baker, L.T., Walker, A.G. (2014). Religiosity and spirituality in entrepreneurship: a review and research agenda. Journal of Management and Spirituality,11(1),159-186. https://doi.org/10.1080/14766086.2013.836127

Bellu, RR, Fiume, P. (2004). Religiosity and Entrepreneurial Behaviour: An Exploratory Study. International Journal of Entrepreneurship and Innovation, 5 (2), 191-201. https://doi.org/10.5367/0000000041513411

Brush, C.G. (1992).Research on women business owners: past trends, a new perspective and future directions. Entrepreneurship Theory and Practice, 16 (4), pp.5-30.

Candland, C. (2001). Faith as social capital: Religion and community development in Southern Asia, in Montgomery.Springer .

Cousins, L.S. (1996). The Dating of the Historical Buddha: A Review Article. Journal of Religion and Society, 6, 57-63. https://doi.org/10.1017/S1356186300014760 
Creswell, J. W. (2007). Qualitative Inquiry and Research Design: Choosing Among Five Approaches. SAGE.

Cullen, M.D.M., Calitz, A.P., Boshoff, L. (2013). Characteristics of the Christian Entrepreneur: An Exploratory Study. Journal of Development and Leadership, 2(1), 23-34.

De Noble, A., Galbraith, C.S., Singh, G., Stiles, C.H. (2007). Market justice, religious orientation, and entrepreneurial attitudes: An empirical study. Journal of Enterprising Communities :People and Places , 1, 121-134. https://doi.org/10.1108/17506200710752548

Delbecq, A.L. (1999). Christian spirituality and contemporary business leadership. Journal of Organizational Change Management, 12, 345-354. https://doi.org/10.1108/09534819910282180

Dodd, S.D., Seaman, P.T. (1998). Religion and Enterprise: An Introductory Exploration. Entrepreneurship Theory and Practice, 23, 71-86. https://doi.org/10.1177/104225879802300104

Dunn, S.L., Jensen, J.D. (2019). Buddhism and Buddhist Business Practices. International Journal of Business Administration, 10, 115- 125. https://doi.org/10.5430/ijba.v10n2p115

Fernando, M., Jackson, B. (2006). The influence of religion-based workplace spirituality on business leaders' decision-making: An inter-faith study. Journal of Management and Organization, 12 (1), 23-39. https://doi.org/10.1017/S1833367200004144

Fry, L. (2003). Toward a theory of spiriytual leadership. The Leadership Quartely, 14(1), 693-727.

Graafland, J.J. and Mazereeuw, C. and Yahia, A. (2006): Islam and socially responsible business conduct: An empirical research among Dutch entrepreneurs. Business Ethics: A European Review, 4 (15), 390-406.

García, M.C.D. and Welter, F. (2011).Gender identities and practices: Interpreting women entrepreneurs' narratives.International Small Business Journal, 16 (1), pp. 1-21.

Griebel, J.M., Park, J.Z. and Neubert, M.J. (2014). Faith and Work: An Exploratory Study of Religious Entrepreneurs. Religions. 5(1), 80-100.

Grine, F., Fares, D., Meguellati, A. (2015). Islamic spirituality and entrepreneurship: A case study of women entrepreneurs in Malaysia. Jounal of Happiness and Wellbeing, 3, 41-56.

Hughes, K.D., Jennings, J.E., Brush, C., Carter, S., Welter, F. (2012). Extending Women's Entrepreneurship Research in New Directions. Entrepreneurship 
Theory and Practice, 36, 429-442. https://doi.org/10.1111/j.15406520.2012.00504.x

Ibrahim, N.A., Angelidis, J.P. (2005). The Long-Term Performance of Small

Businesses: Are there Differences Between "Christian-Based" Companies and their Secular Counterparts?. Journal of Business Ethics, 58, 187-193. https://doi.org/10.1007/s10551-005-1413-8

Jayawardena, T. S. (2017). Ethical Decision Making in Organisations in Sri Lanka: A Budddhist Interpretative Phenomenological Analysis. PhD Thesis. Aukland University of Technology

Kayed, R.N., Hassan, M.K. (2010). Islamic Entreprenurshio: A Case Study of Saudi Arabia. Journal of Developmental Entrepreneurship,15,379-413. https://doi.org/10.1142/S1084946710001634

Khraim, H. (2010). Measuring Religiosity in Consumer Research from an Islamic Perspective. Journal of Economic and Administrative Sciences, 26, 52-78. https://doi.org/10.1108/10264116201000003

Kovács, G., 2014. The theoretical foundation of Buddhist management practices. Journal of Management Development, 33, 751-762. https://doi.org/10.1108/JMD-09-2013-0120

Liu, Z., Xu, Z., Zhou, Z., Li, Y. (2017). Buddhist Entrepreneurs and New Venture Performance: The Mediating Role of Entrepreneurial Risk-Taking. Small Business Economics, vol. 52(3), 713-727.

Mazonde, N.B. and Carmichael, T. (2016). The influence of culture on female entrepreneurs in Zimbabwe. The Southern African Journal of Entrepreneurship and Small Business Management, 8(1), 1015-3977.

Morris, M., Schindehutte, M., 2005. Entrepreneurial Values and the Ethnic Enterprise: An Examination of Six Subcultures. Journal of Small Business Management, 43, 453-479. https://doi.org/10.1111/j.1540627X.2005.00147.x

Moore, D. P. and Buttner, E. H. (1997) .Women entrepreneurs: moving beyond the glass ceiling. Thousand Oaks: Sage Publications.

Nair, K.R.G., Pandey, A.(2006). Characteristics of Entrepreneurs: An Empirical Analysis. The Journal of Entrepreneurship, 15, 47-61. https://doi.org/10.1177/097135570501500104

Parboteeah, K.P., Walter, S.G., Block, J.H. (2014). When Does Christian Religion Matter for Entrepreneurial Activity? The Contingent Effect of a Country's Investments into Knowledge. Journal of Business Ethics, 130, 447-465. 
Ram, A. and Seela A. (2010). 2020 Vision for Gender Sensitive Development and Environment: Commemorative Article for the International Women's Day 2010.

Rarick, C. A. (2007). Enlightened Management: An Analysis of Buddhist Precepts Applied to Managerial Activity. Journal of Global Business Management, 2(1), 33-49. https://ssrn.com/abstract=1021546

Rogers, J.G., Park, J.Z. (2014). Religion and Entrepreneurship: The Role of Religious Beliefs and Values on Female Entrepreneurship, Religion, 5(1),780-800.

Sabah, S. (2016). Entrepreneurial Intention: Theory of Planned Behaviour and the Moderation Effect of Start-Up Experience, Entrepreneurship - PracticeOriented Perspectives. Journal of Psychology, 2(1),88101.https://doi.org/10.5772/65640

Sachayansrisakul, N. (2016). Positive influences of 'Buddhism' on successful female entrepreneurs. World Review of Entrepreneurship, Management and Sustainable Development, 12 ( 2/3), 352-362.

Shepherd, D.A., Williams, T.A., Patzelt, H. (2015). Thinking About Entrepreneurial Decision Making: Review and Research Agenda. Journal of Management, 41(1), 11-46. https://doi.org/10.1177/0149206314541153

Spiliakos, A. (2018). What does sustainability mean in business.Sustainable Business Strategy, 10(2), 112-119.

Surangi, H.A.K.N.S. (2018). What influences the networking behaviours of female entrepreneurs?: A case for the small business tourism sector in Sri Lanka". International Journal of Gender and Entrepreneurship,10(1), 1-19.

Thornton, P.H., Ocasio, W. (2008). Institutional Logics, Sage Publication. https://doi.org/10.4135/9781849200387.n4

Tolbert, P.S., David, R.J., Sine, W.D. (2011). Studying Choice and Change: The Intersection of Institutional Theory and Entrepreneurship Research. Journal of Organizational Science, 22(1), 1332-1344. https://doi.org/10.1287/orsc.1100.0601

Tulus, T. (2009) .Women entrepreneurship in Asian developing countries: Their development and main constraints. Journal of development and Agricultural Economics, 1 (2), pp 27-40.

UN (2003) Economic and social commission for Asia and Pacific: putting gender mainstreaming into practice: UN.

UNESCAP (2005) Economic and social commission for Asia and Pacific: developing women entrepreneurs in south Asia: issues, initiatives and experiences: UNESCAP. 
Valliere, D. (2008). Exploring Buddhist influence on the entrepreneurial decision. International Journal of Entreprenurship and Behaviourial Research, 14(1), 172-191. https://doi.org/10.1108/13552550810874682

Weber, M. (1930). The Protestant Ethic and the Spirit of Capitalism. Routledge Taylor and Francis Group.

Weerasinghe, T.D., Thisera, T.J.R., Kumara, RHGWP (2015). Buddhism and Organizational Management: A Review. Kelaniya Journal of Management 3(1), 93- 112. https://doi.org/10.4038/kjm.v3i2.7484

Worden S. 2005. Religion in Strategic Leadership: A Positivistic, Normative/Theological and Strategic Analysis. Journal of Business Ethics, 57(3):221-239. 